Dicle Tıp Dergisi / Dicle Med J (2019) 46 (1) : 119 - 124

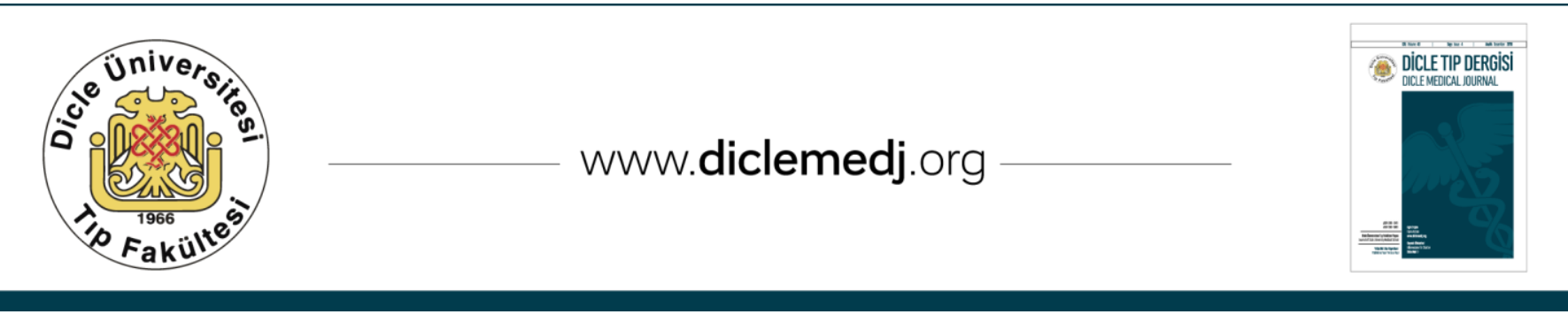

Özgün Araștırma / Original Article

\title{
Alternative methods for the diagnosis of macroprolactinemia: urine prolactin level and serum / urine prolactin ratio
}

\author{
Zafer Pekkolay1, Mazhar Müslüm Tuna'², Mehmet Güven³ ${ }^{3}$ Şadiye Altun Tuzcu', \\ İbrahim Kaplan' ${ }^{5}$ Zeki Akkuş, Alpaslan Kemal Tuzcu ${ }^{7}$ \\ 1 Dicle University Faculty of Medicine, Department of Internal Medicine-Endocrinology, Sur, Diyarbakir, Turkey ORCID: 0000-0002-5323-2257 \\ 2 University of Health Sciences Umraniye Training and Research Hospital, Department of Internal Medicine-Endocrinology, Umraniye, Istanbul, Turkey \\ ORCID: 0000-0001-5975-7786 \\ 3 Dicle University Faculty of Medicine, Department of Internal Medicine-Endocrinology, Sur, Diyarbakir, Turkey ORCID: 0000-0002-0752-8815 \\ 4 University of Health Sciences Gazi Yasargil Training and Research Hospital, Yenisehir, Diyarbakir, Turkey ORCID: 0000-0003-3326-5358 \\ 5 Dicle University Faculty of Medicine, Department of Biochemistry, Sur, Diyarbakir, Turkey ORCID: 0000-0003-2813-1064 \\ 6 Dicle University Faculty of Medicine, Department of Biostatistics and Medical Informatics, Sur, Diyarbakir, Turkey 0RCID: 0000-0002-6161-3666 \\ 7 Dicle University Faculty of Medicine, Department of Internal Medicine-Endocrinology, Sur, Diyarbakir, Turkey ORCID:0000-0002-1814-9773
}

Received: 02.11.2018; Revised: 08.11.2018; Accepted: 14.12.2018

\begin{abstract}
Objective: The aim of this study was to investigate the urine prolactin and serum/urine prolactin ratio for accuracy diagnosis of macroprolactinemia.

Methods: In the retrospective cross-sectional analysis, prolactin levels (high or normal) in the reproductive period of men and women were included in the study. Polyethylene glycol (PEG) precipitation method was used for the detection of macroprolactinemia. Then, patients were divided into three groups as macroprolactinemia, prolactinoma and healthy control group. In patients, prolactin values in spot urine with simultaneous serum prolactin values were calculated. The non-parametric Kruskal-Wallis test was used to compare the groups. The receiver-operating characteristic (ROC) curve was determined to evaluate the predictive power of serum/urine prolactin ratio.

Results: A total of 41 patients were included in the study. Female/male:36 (87.8\%)/ 5 (12.2\%). Urinary prolactin median(minimum-maximum) values were macroprolactinemia, prolactinoma and control group, respectively; $0.06(0.05-0.10), 0.11(0.02-0.95), 0.08(0.05-0.25) \mathrm{ng} / \mathrm{ml}$. Serum/urine ratio median (minium-maximum) values were macroprolactinemia, prolactinoma, and control group, respectively; 633(51-1032), 990(104-9635), 395.5(138-953). When the groups were compared, the patients with prolactinoma had higher urinary prolactin levels(p <0.01). Serum/urine prolactin ratio was found to be the highest in prolactinoma patients and the lowest in the control group and a significant difference was observed in groups $(\mathrm{p}<0.01)$.
\end{abstract}


ROC analysis(control-macroprolactin) for serum/urine prolactin ratio (Sensitivity 84.6 specificity 93.7 cut off $>549,5$ AUC $=0.83) \mathrm{p}<0.01$

Conclusion: Urinary prolactin level and serum/urine prolactin ratio may be used in diagnosis of macroprolactinemia.

Keywords: macroprolactinemia, urine prolactin, serum/urine prolactin ratio

\section{Makroprolaktinemi tanısı için alternatif yöntemler: İdrar prolaktin düzeyi ve serum / idrar prolaktin oranı}

\section{Öz}

Amaç: $\mathrm{Bu}$ çalışmanın amacı makroprolaktinemi tanısında idrar prolaktin ve serum / idrar prolaktin oranının doğruluğunu araştırmaktır.

Yöntemler: Kesitsel analiz olan çalışmamızda, reprodüktif dönemdeki kadın ve erkeklerden prolaktin düzeyi bakılan (yüksek veya normal) hastalar çalışmaya alındı. Makroprolaktinemi tespiti için polietilen glikol (PEG) ile çöktürme yöntemi kullanıldı. Daha sonra hastalar makroprolaktinemi, prolaktinoma ve sağlıklı kontrol grubu olmak üzere üç gruba ayrıldı. Hastalarda eş zamanlı serum prolaktin ve spot idrarda prolaktin çalışıldı. Non-parametrik test olan Kruskal-Wallis testi grupların karşılaştırılmasında kullanıldı. Serum/idrar prolaktin oranının prediktif gücünü değerlendirmek için "receiver-operating characteristic (ROC)" eğrisi belirlendi ve bu analizde "cut-off" değeri elde edildi.

Sonuçlar: Çalışmaya toplam 41 hasta dahil edildi. Kadın/erkek: $36(\% 87,8)$ / $5(\% 12,2)$. İdrar prolaktin medyan (minimum-maksimum) değerleri makroprolaktinemi, prolaktinoma ve kontrol grubunda sirasıyla; 0.06(0.05-0.10), 0.11(0.02-0.95), 0.08(0.05-0.25) ng/ml idi. Serum/idrar prolaktin oranı medyan (minimum-maksimum) değerleri makroprolaktinemi, prolaktinoma ve kontrol grubunda sırasıyla; 633(51-1032), 990(104-9635), 395.5(138-953) idi. Gruplar karşılaştırıldığında prolaktinoma olan hastalar daha yüksek üriner prolaktin seviyelerine sahipti. Makroprolaktinemili hastalar en düşük idrar prolaktin değerlerine sahipti $(\mathrm{p}<0.01)$. Prolaktinoma hastalarında serum / idrar prolaktin oranı en yüksek, kontrol grubunda ise en düşük bulundu ve gruplar arasında anlamlı fark bulundu (p $<0.01)$.

Serum/idrar prolaktin oranı için ROC analizi (kontrol-makroprolaktin) (Duyarlılık 84.6 özgüllük 93.7 cut off> 549,5 AUC $=0.83) \mathrm{p}<0.01$

Sonuç: Makroprolaktinemi tanısında idrar prolaktin düzeyi ve serum/idrar prolaktin oranı kullanılabilir.

Anahtar kelimeler: Makroprolaktinemi, idrar prolaktini, serum/idrar prolaktin oranı.

\section{INTRODUCTION}

Prolactin is secreted by lactotroph cells in the anterior pituitary. It provides proliferation and differentiation of mammary glands, initiates and maintains lactation. Rise of serum prolactin disrupts gonadal functions. Causes infertility in men and women ${ }^{1-3}$.

The majority of the prolactin in serum (8595\%) constitutes monomeric prolactin (23 $\mathrm{kDA}$ ) which is biologically active and has a low molecular weight. Most of the remaining part is dimeric prolactin form (50 kDA) while macroprolactin (150-170 kDA) is much less ${ }^{4}$.
Macroprolactinemia, despite high prolactin, does not have hyperprolactinemic symptoms ${ }^{5}$.

Macroprolactin is generally a complex of monomeric prolactin and Ig G. Because it has a large molecular structure, it cannot pass through capillaries and cannot function biologically. It usually does not form any symptoms. In physiological conditions, less than $20 \%$ of total prolactin in the blood is macroprolactin. Macroprolactinemia is mentioned when the circulating macroprolactin level is more than $30 \%$. The biggest problem with macroprolactinemia is the evaluation and treatment of the disease as prolactinoma ${ }^{6-8}$. 
Polyethylene glycol (PEG) precipitation method is mostly used for the diagnosis of macroprolactinemia. However, it is a test performed in advanced centers ${ }^{9-12}$.

Normally monomeric prolactin is excreted in the urine. The prolactin fraction in prolactinoma is the monomeric form. Macroprolactin is not detected in urine. Prolactin clearance decreases in macroprolactinemia; the amount in the blood increases ${ }^{13}$.

The aim of this study was to investigate urine prolactin and serum/urine prolactin ratio in patients with suspicion of macroprolactinemia and to determine whether these tests would be used to differentiate hyperprolactinemia.

\section{METHODS}

In the retrospective cross-sectional analysis, prolactin levels (high or normal) in the reproductive period of men and women were included in the study. Pregnancy, lactation, creatinine elevation and chronic disease were excluded from the study. Polyethylene glycol (PEG) precipitation method was used for the detection of macroprolactinemia. Then, patients were divided into three groups as macroprolactinemia, prolactinoma and healthy control group.

In patients, prolactin values in spot urine with simultaneous serum prolactin values were measured by Roche-cobas 6001 device by electrocemiluminescence method.

In our laboratory, normal value of serum prolactin was 4.79-23.3 ng / ml.

Statistical analysis was performed using SPSS version 22 . The suitability of the variables to normal distribution was examined using visual and analytical methods. Urine prolactin and serum/urine prolactin ratio did not comply with normal distribution. The non-parametric Kruskal-Wallis test was used to compare the groups. Mann-Whitney U test was used for

Table 1: Patient characteristics. paired comparisons and evaluated using Bonferroni correction. The receiver-operating characteristic (ROC) curve was determined to evaluate the predictive power of serum/urine prolactin ratio. In this analysis, cut-off value was obtained. The sensitivity and specificity of the cut-off value in the detection of macroprolactinemia / prolactinoma were calculated. Also, the area under the ROC curve was calculated. The statistical significance limit was accepted as $<0.05$.

Ethical approval was obtained from the local ethics committee before the study (Dicle University 262/2018).

Informed consent form was obtained from the patients who participated in the study.

\section{RESULTS}

A total of 41 patients were included in the study. Female/male:36 (87.8\%)/ 5 (12.2\%). Prolactinoma, macroprolactinemia and control group consisted of 16 (39\%), 14 (34\%), 11 (27\%) patients, respectively. Urinary prolactin median (minimum- maximum) values were macroprolactinemia, prolactinoma and control group, respectively; 0.06(0.05-0.10), 0.11(0.02$0.95), \quad 0.08(0.05-0.25) \mathrm{ng} / \mathrm{ml}$. There was a statistical difference between the groups. Posthoc analysis was performed using the Mann-Whitney $U$ test with Bonferroni correction. When the groups were compared, the patients with prolactinoma had higher urinary prolactin levels $(\mathrm{p}<0.01)$. Serum/urine ratio median (minium-maximum) values were macroprolactinemia, prolactinoma, and control group, respectively; 633 (51-1032), 990(1049635), 395.5(138-953). Serum / urine prolactin ratio was found to be the highest in prolactinoma patients and the lowest in the control group and a significant difference was observed in the control group $(p<0.01)$ (Table 1). 


\begin{tabular}{|lcccc|}
\hline & macroprolactinemia & prolactinoma & control & p value \\
\hline $\begin{array}{l}\text { n (Total:41) } \\
\text { Female/male 36/ } 5\end{array}$ & $14(34 \%)$ & $16(39 \%)$ & $11(27 \%)$ & \\
\hline $\begin{array}{l}\text { urine prolactin } \\
\text { median (min.-max.) }\end{array}$ & $0.06(0,05-0,10)$ & $0,11(0,02-0,95)$ & $0,08(0,05-0,25)$ & $\mathrm{p}<0.01$ \\
\hline $\begin{array}{l}\text { serum/urine ratio } \\
\text { median(min.-max.) }\end{array}$ & $633(51-1032)$ & $990(104-9635)$ & $395,5(138-953)$ & $\mathrm{p}<0.01$ \\
\hline
\end{tabular}

ROC analysis(control-high prolactin) for serum/urine prolactin ratio (Sensitivity 74.2 specificity 91.7 cut off $>499$ AUC $=0.79$ ) $p<0,01$ (Figure 1), (Table 2).

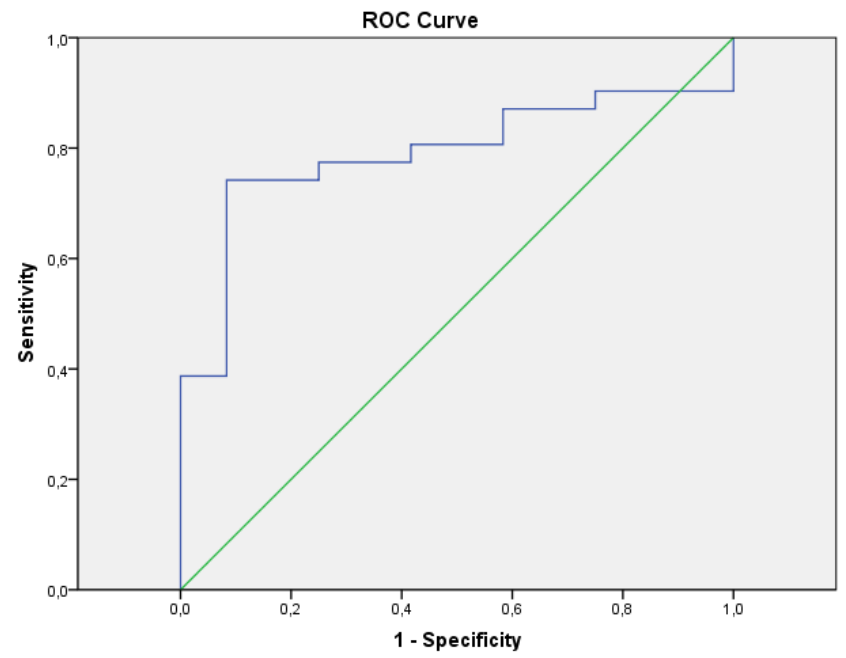

Figure 1: Serum/idrar ratio Roc analysis(high prolactin- control) (AUC:0.79, p<0.01) Sensistivity 74.2 Specificity 91.7 cut off $>499$ )

ROC analysis(control-macroprolactin) for serum/urine prolactin ratio (Sensitivity 84.6 specificity 93.7 cut off $>549,5 \quad$ AUC $=0.83$ ) $\mathrm{p}<0.01$ (Figure 2), (Table 2).

Discussion: Macroprolactin is a form of prolactin that is not produced by the pituitary. It is a complex structure made by monomeric

forms with antibodies in peripheral blood. Due to the size of the molecule can not reach the prolactin receptors, remains in the serum. No symptoms are expected. Macroprolactin leads to prolactin elevation in serum. Therefore, it is mistakenly treated like prolactinoma. This situation leads to unnecessary treatment of patients and economic loss ${ }^{14}$.

Table 2: Analysis of serum/urine prolactin ratio.

\begin{tabular}{|c|c|c|}
\hline & Cut-off & Comment \\
\hline Macroprolactin versus control & $>549,5$ & Macroprolactin \\
\hline High prolactin versus control & $>499$ & $\begin{array}{l}\text { Macroprolactin or } \\
\text { prolactinoma }\end{array}$ \\
\hline
\end{tabular}

We did not find any article in our literature search with the terms "macroprolactinemia and urine", "serum / urine prolactin ratio".

We found that urine prolactin levels, which is a new method for the differentiation of hyperprolactinemia, were found to be lower in patients with macroprolactinemia compared to the healthy population and found statistically significant.

There is little literature on urinary prolactin. The first publication on urinary prolactin belongs to $1951^{15}$.

Studies are related to urine levels of monomeric prolactin. 


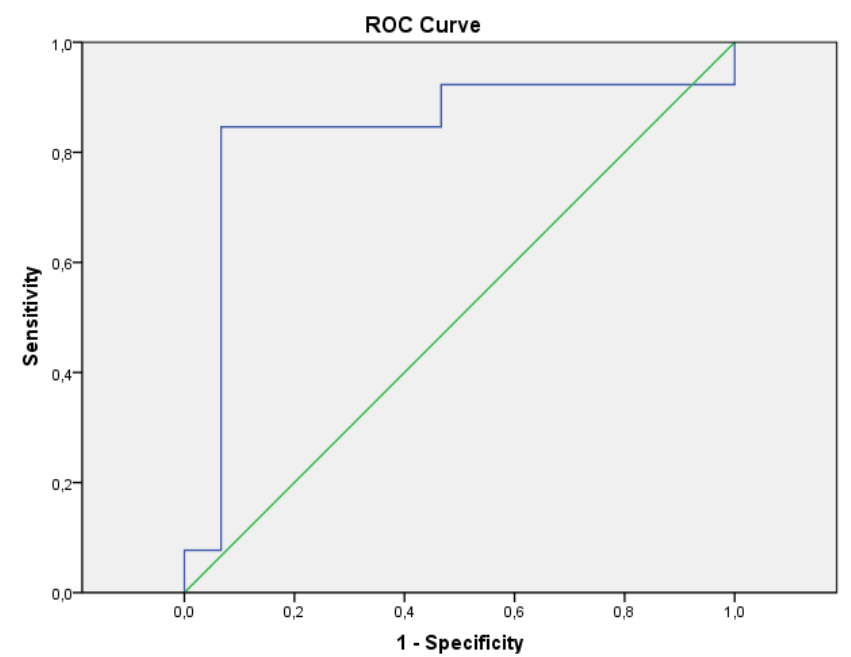

Figure 2: Roc analysis(macroprolactin-control) (AUC:0.83, $\mathrm{p}<0.01$ ) Sensistivity 84.6 Specificity 93.7 cut off $>549,5$ )

Miranda et al. studied that urinary prolactin levels in patients with preeclampsia and found a positive correlation between urinary prolactin level and severity of disease ${ }^{16}$.

Keely et al. found that serum concentration of monomeric prolactin was positively related to urine concentration and urine / serum ratio was found to be approximately $1 / 2000^{17}$.

In our study, we expect the serum / urine prolactin ratio to contribute to the differential diagnosis of hyperprolactinemia. In our study, the serum / urine ratio was the highest in prolactinoma and the lowest in the control group. This shows that the excess monomeric prolactin is excreted in the urine. Macroprolactinemia was also higher in serum / urine than control group. Macroprolactin is not excreted in urine.

We found that cut-off value $>499$ in serum / urine ratio compared to control group with high prolactin. The serum / urine ratio cut-off value was found to be $>549.5$ when compared with the control group with macroprolactinemia. Measuring simultaneous serum and urine prolactin can differentiate normal patients from macroprolactinemia / prolactinoma.
Limitations: Low number of patients. Although serum creatinine levels of all patients included in the study were normal, urinary prolactin was not corrected according to creatinine level.

Our prospective recommendations: Urinary prolactin and serum / urine prolactin ratio cutoff values for differential diagnosis of macroprolactinemia can be determined by studies with a greater number of patients.

In conclusion, urinary prolactin level and serum / urine prolactin ratio may be used in diagnosis of macroprolactinemia. This new method may be an alternative to polyethylene glycol and other complex methods.

Declaration of Conflicting Interests: The authors declare that they have no conflict ofinterest.

Financial Disclosure: No financial support was received.

\section{REFERENCES}

1. Horseman ND and Gregerson KA. Prolactin actions. Journal of Molecular Endocrinology. 2014; 52: 95-106.

2. Melmed S, Casanueva FF, Hoffman AR, et all. Endocrine Society. Diagnosis and treatment of hyperprolactinemia: an Endocrine Society clinical practice guideline. J Clin Endocrinol Metab. 2011; 96: 273-88.

3. Freeman ME, Kanyicska B, Lerant A, et all. Prolactin: structure, function, and regulation of secretion. Physiological Reviews. 2000; 80: 1523-631.

4. Molitch ME. Prolactin in human reproduction In: Strauss JF, Barbieri R, eds. Yen and Jaffe's reproductive endocrinology: physiology, pathophysiology, and clinical management, 7 th edn. Elsevier Saunders, Philadelphia 2014: 45-65.

5. Hattori N, Ishihara $\mathrm{T}$, Saiki $\mathrm{Y}$, et all. Macroprolactinaemia in patients with hyperprolactinaemia: composition of macroprolactin and stability during long-term follow-up. Clin Endocrinol (Oxf). 2010; 73: 792-7.

6. Hattori N, Nakayama Y, Kitagawa K, et all. Antiprolactin (PRL) autoantibody-binding sites (epitopes) on PRL molecule in macroprolactinemia. Clin Endocrinol (Oxf). 2006; 190: 287-93. 
7. Freeman ME, Kanyicska B, Lerant A, et all. Prolactin: structure, function, and regulation of secretion. Physiol Rev. 2000;80:1523-631.

8. Samson SL, Hamrahian AH, Ezzat S. American Association of Clinical Endocrinologists. American College of Endocrinology disease state clinical review: clinical relevance of macroprolactin in the absence or presence of true hyperprolactinemia. Endocr Pract. 2015; 21: 1427-35.

9. Hattori N, Ishihara $\mathrm{T}$, Saiki $\mathrm{Y}$, et all. Macroprolactinaemia in patients with hyperprolactinaemia: composition of macroprolactin and stability during long-term follow-up. Clinical Endocrinology. 2010; 73: 792-7.

10. Jamaluddin FA, Sthaneshwar P, Hussein Z, et all. Importance of screening for macroprolactin in all hyperprolactinaemic sera. Malays J Patho. 2013; 35: 59-63.

11. Leslie H, Courtney CH, Bell PM, et all. Laboratory and clinical experience in 55 patients with macroprolactinemia identified by a simple polyethylene glycol precipitation method. J Clin Endocrinol Metab. 2001; 86: 2743-6.
12. Silva AM, Costa da PM, Pacheco A, et all. Assessment of macroprolactinemia by polyethylene glycol precipitation method. Revista Portuguesa de Endocrinologia, Diabetes e Metabolismo 2014; 9: 2528.

13. Snyder PJ, Causes of hyperprolactinemia. https://www.uptodate.com/contents/causes of hyperprolactinemia.

14. Smith TP, Kavanagh L, Healy ML, et all. Technology insight: measuring prolactin in clinical samples. Nature Reviews Endocrinology. 2007; 3: 279-89.

15. Coppedge RL, Segaloff A. Urinary Prolactin Excretion In Man, The Journal of Clinical Endocrinology \& Metabolism. 1951; 11: 465-76.

16. Leaños-Miranda A, Márquez-Acosta J, CárdenasMondragón GM, et all. Urinary prolactin as a reliable marker for preeclampsia, its severity, and the occurrence of adverse pregnancy outcomes. J Clin Endocrinol Metab. 2008; 93: 2492-9.

17. Keely EJ, Charles F. Measurement of human urinary prolactin as a noninvasive study tool. Clinical chemistry. 1994; 40: 2017-21. 